\title{
Insurance Value of Green Infrastructure in and Around Cities
}

\author{
Tom L. Green, ${ }^{1 *}$ Jakub Kronenberg, ${ }^{2}$ Erik Andersson, ${ }^{3}$ Thomas Elmqvist, ${ }^{3}$ \\ and Erik Gómez-Baggethun ${ }^{4,5}$
}

\begin{abstract}
${ }^{1}$ Centre for Dialogue, Simon Fraser University, 3305 - 515 Hastings Street West, Vancouver, British Columbia V6B 5K3, Canada;
${ }^{2}$ Department of International Economics, University of Lodz, P.O.W. 3/5, 90-255 Lodz, Poland; ${ }^{3}$ Stockholm Resilience Centre, Stockholm University, Kräftriket 2B, 10691 Stockholm, Sweden; ${ }^{4}$ Norwegian Institute for Nature Research (NINA), Gaustadalléen 21, 0349 Oslo, Norway; ${ }^{5}$ Department of International Environment and Development Studies, Norwegian University of Life Sciences
\end{abstract} (NMBU), Universitetstunet 3, 1430 Ås, Norway

\begin{abstract}
The combination of climate change and urbanization projected to occur until 2050 poses new challenges for land-use planning, not least in terms of reducing urban vulnerability to hazards from projected increases in the frequency and intensity of climate extremes. Interest in investments in green infrastructure (interconnected systems of parks, wetlands, gardens and other green spaces), as well as in restoration of urban ecosystems as part of such adaptation strategies, is growing worldwide. Previous research has highlighted the insurance value of ecosystems in securing the supply of ecosystem services in the face of disturbance and change, yet this literature neglects urban areas even though urban populations are often highly vulnerable. We revisit the insurance value literature to examine the applicability of the concept in urban contexts, illustrating it with two case studies: watersheds providing drinking water for residents of Vancouver, Canada; and private gardens ensuring con-
\end{abstract}

nectedness between other parts of urban green infrastructure in London, UK. Our research supports the notion that investments in green infrastructure can enhance insurance value, reducing vulnerability and the costs of adaptation to climate change and other environmental change. Although we recommend that urban authorities consider the insurance value of ecosystems in their decisionmaking matrix, we advise caution in relying upon monetary evaluations of insurance value. We conclude by identifying actions and management strategies oriented to maintain or enhance the insurance value of urban ecosystems. Ecosystems that are themselves resilient to external disturbances are better able to provide insurance for broader social-ecological systems.

Key words: social-ecological systems; urban ecology urban ecosystem services; resilience; nature-base solutions; ecosystem restoration.
Received 23 March 2015; accepted 13 March 2016; published online 12 May 2016

Author contributions TG, JK, TA, TE, EG Conceived of or designed study; TG, JK and EA performed research; TG and JK analysed data; TG, JK, EA, TE, EG wrote the paper.

*Corresponding author; e-mail: tom@viableeconomics.com

\section{INTRODUCTION}

In 2030, 5 billion people will live in cities. Urban land cover is projected to increase $200 \%$ between 2000 and 2030 , meaning that roughly $60 \%$ of urban areas existing in 2030 will have been built within this period (Elmqvist and others 2013). These trends imply massive investment in urban infrastructure and profound transformations in urban ecosystems and landscapes. The increased frequency and 
intensity of environmental extremes expected with climate change will increase the risk of disruptions in ecosystem capacity to sustain the delivery of ecosystem services, posing new adaptation challenges to cities (Wamsler and others 2013).

Auspiciously, civic authorities around the world are increasingly interested in investment in green infrastructure as an adaptation strategy to cope with environmental extremes (Tzoulas and others 2007; Elmqvist and others 2013; Horizon 2020 Expert Group 2015). For example, urban forests are increasingly recognized for their capacity to reduce the health impacts experienced by urban residents during heat waves, and increasing attention is being paid to ensuring that green areas can absorb sudden flows of stormwater (Depietri and others 2012; Farrugia and others 2013).

The societal importance of ecosystems and biodiversity in buffering shocks, thereby sustaining resilience in social-ecological systems, is increasingly examined through the metaphor of insurance value. Referring to the insurance value offered by ecosystems suggests that there is a critically important value in the structure and core ecosystem processes responsible for maintaining ecosystem resilience against shocks; this property ultimately determines ecosystems' capacity to sustain a multitude of other ecosystem services over time (Gómez-Baggethun 2010, 2013). As noted by Baumgärtner and Strunz (2014), investing in the insurance capacity of ecosystems "keeps an ecosystem in a desirable domain" and helps "to prevent catastrophic and irreversible reductions in ecosystem service flows".

Urban areas are challenging for the insurance value literature because urban ecosystems tend to be highly altered and fragmented, with biodiversity affected by losses of endemic species and gains of invasive species. Moreover, urban areas depend to a large extent on green infrastructure beyond their boundaries. We review the role urban ecosystems can play in offering insurance value against natural disturbance or management error. Our goals are to (i) present a summary of the meanings attached to insurance value; (ii) illustrate its importance through two case studies of investments in urban and peri-urban green infrastructure; and (iii) identify strategies for enhancing insurance value so as to build resilience in urban areas.

We start by providing terminological clarification of key concepts used in the manuscript. Insurance value reflects an ecosystem's capacity to remain in a given regime and retain its capacity to deliver vital ecosystem services in the face of disturbance and change (Baumgärtner 2007). Following Mayer and Rietkerk (2004), regime is used here to refer to the notion that ecosystems operate dynamically within a distinctive range, where particular species, energy flows and trophic structures tend to dominate as a result of internal feedback patterns. By regime shift, we refer to instances where as a result of disturbance or management error, an ecosystem shifts from one regime to another, often with impaired capacity to sustain ecosystem services (Crépin and others 2012). By disturbance, we mean an event that disrupts ecosystem structure and changes resource availability or the physical environment (White and Pickett 1985). Our focus is on disturbances and resource management errors that can affect flows of ecosystem services supplied by urban ecosystems, with particular attention to those that have the potential to cause regime shifts.

By urban, we refer not just to the urban core, but also to urban peripheries and adjacent ecosystems inextricably linked to the urban region. We recognize that cities affect environments beyond their borders through connections involving flows of energy, and materials at different scales of space and time (Seto and others 2012; Liu and others 2013). Cities are also affected by events at different scales and localities (Jansson 2013). However, since a given city does not have jurisdiction on such distant ecosystems and since such ecosystems are impacted by the combined demands of many urban areas, we concentrate on case studies where green infrastructure that is relevant for insurance value remains under the city's direct influence. Finally, green infrastructure is defined as a network of ecosystem structures with other environmental features that are designed and managed to deliver a wide range of ecosystem services (European Commission 2013).

The remainder of the paper proceeds as follows. First, we review the ecological and economic foundations of insurance value, deriving key insights relevant to urban areas. Next, we substantiate these insights by examining two cases where cities have invested in green infrastructure, augmenting the insurance value offered by urban ecosystems. With this foundation, we examine the potential for building resilience in cities through investment in the insurance value of green infrastructure. We end with concluding remarks and policy recommendations to promote insurance value in urban areas.

\section{Ecological and Economic Foundations OF INSURANCE VALUE}

The proposition that biodiversity and healthy ecosystems offer humans a form of insurance originated in the ecology literature in the mid- 
1950s (MacArthur 1955; Elton 1958; Hutchinson 1959). Early contributions were largely grounded in the proposition that ecosystems with more species and functions are able to absorb perturbations better than ecosystems with fewer species and functions (Gross and others 2014). Following Holling's (1973) seminal contribution on ecosystem resilience, this thesis was further investigated and debated amongst ecologists (McCann 2000), and the notion eventually found its way into the environmental and ecological economics literatures (Perrings 1995; Yachi and Loreau 1999; Mäler 2006, 2008; Baumgärtner 2007; Sukhdev and others 2010). Thus, the metaphor draws on both ecological and economic foundations.

\section{Ecology}

The idea of insurance as connected to biodiversity and ecological structures stems from suggestive evidence from both empirical work and modelling exercises. Very broadly, biodiversity is thought to compensate for fluctuations in the population of individual species and the functions they perform within ecosystems (Ehrlich and Ehrlich 1981; Walker 1992; Grime 1997; Loreau and others 2001). Ehrlich and Ehrlich (1981) likened species that perform similar ecological functions using the metaphor of an airplane: the plane can still fly even if you lose some of the rivets. However, seemingly redundant species must be able to shift in their relative contributions to a specific function, creating a balanced response to changes in the system where some species increase while others decrease. This variable response is dealt with in detail under the label "response diversity", that is, variation within functional response traits (Elmqvist and others 2003; Mori and others 2013).

At the larger landscape, or regional scale, insurance has been addressed as spatial resilience, where a local ecosystem's capacity to reorganize and retain function after disturbance is related to its connections with its surroundings and with internal factors (Nyström and Folke 2001; Bengtsson and others 2003). Spatial resilience relies on redundancy as well, but redundancy at the system rather than species level. By being connected to undisturbed sites, a disturbed site can regain species and ecological functions through meta-population (Hanski 1999) or meta-community (Loreau 2010) processes. However, there is a seeming paradox or trade off that must be dealt with when thinking about connectivity in relation to resilience or insurance. On the one hand, connectivity facilitates movement and exchange between system compo- nents and is a prerequisite for meta-population dynamics and spatial resilience. On the other, modularity in the form of at least partial component isolation can prevent synchronicity on large scales and can buffer against cascading disasters and disease epidemics (Levin 1998; Lundberg and Moberg 2003; Friess and others 2015).

Folke and others (1996) argued that measures to conserve or increase biodiversity-and thereby promote ecosystem resilience-are justified even in heavily impacted ecosystems. They identified a key objective of conservation as avoiding regime shifts by maintaining functional diversity and keystone species. In the urban setting, the most direct relevance of these ideas is as applied to the sustained supply of ecosystem services in the face of disturbance and change (Gómez-Baggethun and Barton 2013; Hubacek and Kronenberg 2013). Many ecological functions are directly related to ecosystem services, and the mechanisms for stabilizing or recovering functions thus hold for ecosystem services as well. Where the response diversity to expected disturbances is low, urban ecosystems are unlikely to offer meaningful degrees of insurance value. The threshold where insurance value stops being meaningful depends on the biodiversity present in each city, as well as the specific disturbance regime.

Finally, some species communities and ecosystems also protect other parts of urban systems or reduce the impact of disturbances. Among the better-studied examples are ecosystems that provide a physical barrier from storm surges (Costanza and others 2006; Koch and others 2009), that protect from flooding through percolation (Farrugia and others 2013) and that mitigate heat waves (Jenerette and others 2011; Depietri and others 2012). To have insurance value, these structures must fit spatially with the vulnerable areas (for example, by providing a barrier between the source of a disturbance and potential sufferers), and be sufficiently sized to match the magnitude of the disturbance.

\section{Economics}

Welfare economics is often used to support decisions with the aim of ensuring the efficient allocation of resources. In a cost-benefit analysis framework, relevant costs and benefits must be accounted for. Increasingly, economists have come to recognize that an ecosystem's contribution to welfare will be understated if the analysis accounts for flows of ecosystem services, but fails to also account for insurance value (Gómez-Baggethun 
2010, 2013; Baumgärtner and Strunz 2014). In line with such suggestions, The Economics of Ecosystem Biodiversity (TEEB) initiative defined insurance value as "the value of ensuring that there is no regime shift in the ecosystem with irreversible negative consequences for human well-being" (Pascual and others 2010). Although this definition is consistent with the ecological approach, it added that insurance offered by ecosystems has an associated economic value.

Methodologies for monetizing the insurance value of resilience are in their infancy (Baumgärtner and Strunz 2014). Some economists have tried to estimate the monetary value of insurance from ecosystems as a substitute for insurance offered in the financial market (for example, Perrings 1995). Others have taken advantage of data collected in the agricultural sector to empirically examine how the level of agro-biodiversity relates to resilience and to estimate insurance value in monetary units (Schläpfer and others 2002; Koellner and Schmitz 2006; Di Falco and Chavas 2008; Abson and others 2013).

Such exercises have illustrative power, but the usefulness of monetary metrics for understanding insurance value remains debated. Attempts to monetize resilience require a very high degree of simplification, and-as argued by Mäler (2008) - "it may seem overoptimistic to discuss economic valuation of a stock we know so little about". Furthermore, recent scholarship exploring the monetary dimension of insurance value has suggested that financial insurance that compensates for losses in ecosystem services can reduce an individual resource manager's need to make investments in natural capital and maintain biodiversity (Quaas and Baumgärtner 2008). Essentially, if financial equivalents are available to help ecosystem managers adjust to the changes in flows of ecosystem services entailed by a regime shift (Baumgärtner 2007), then managers will choose the most cost-effective option when deciding whether to invest in financial insurance or ecosystem resilience. Such an outcome is not socially efficient. If ecosystem managers are not risk averse, insurance value will be zero or negative (Baumgärtner 2007); insurance value is irrelevant to risk-neutral or risk-loving individuals. These considerations may be seen to reveal the limitations entailed in relying upon an economic perception of nature as a substitute for products and services available in the market (Kronenberg 2014). These challenges are also evident in more specific models of insurance value summarized in the following paragraphs.
Strunz and Baumgärtner (2010) examined the value of ecosystem resilience using a stylized economic model where the probability of a regime shift is somehow known. Their perhaps counterintuitive finding was that in most cases, the economically rational ecosystem manager may choose zero investment in resilience. Full investment in resilience is selected where the manager is "rather risk-averse" and the full costs of investing in resilience are less than the potential income loss from the loss of ecosystem services. However, in cases where investments in resilience would be costly and would be relatively ineffective at reducing the likelihood of a regime shift, the economically rational manager gives up on resilience and prepares for regime change.

Baumgärtner and Strunz (2014) used a theoretical model and a welfare economics analytical framework to explore the economic insurance interpretation of resilience. They referred to the financial literature to understand insurance as something that mitigates income uncertainty. They viewed resilience's insurance value as its ability to reduce an ecosystem user's income risk in the event of changes in available ecosystem services due to unpredictable future disturbances. Here, users who conform to the rational actor model only care about income (or benefits) from ecosystem services and are disinterested in ecosystem states per se. One of the authors' findings with important implications for conservation and urban areas was that for low levels of resilience, insurance value can be negative. Investments in resilience may only be warranted if they get the ecosystem above the threshold wherein recovery from disturbance is likely.

The theoretical contributions in the two papers by Baumgärtner and Strunz raise important questions about efforts to develop monetary estimates of insurance value in urban areas, where ecosystems tend to be degraded. According to their models, the monetized insurance value of degraded urban ecosystems will often be negative. In instances where investments in restoration are unlikely to avoid regime shifts, the increase in insurance value offered by such restoration will be slight and probably insufficient to demonstrate that the investments in question would be economically efficient. However, if restoration increases ecosystem services, the combined increase in value of ecosystem services and insurance value may tip the scales in favour of restoration.

Limburg and others (2002) noted that when the identification of ecological thresholds is uncertain or unknown (which is most often the case), mon- 
etary valuation at the margin can be misleading and unlikely to provide the economic signals required to avert regime shifts. In such cases, it is more appropriate to focus on biophysical measurement of slow-changing variables and early warning indicators (Gómez-Baggethun 2010, 2013; Pascual and others 2010). In a similar vein, Admiraal and others (2013) combined insights from ecology and portfolio theory and argued that decisions intended to optimize total economic value should be subject to a constraint wherein sufficient functional diversity is maintained so as to prevent regime shifts; the desired flows of ecosystem services, as well as an ecosystem's insurance value, are thereby secured. They argued that without a requirement for precautionary management, given that valuation methods are inadequate to the task, there is no guarantee that decisions informed by monetary valuation will lead to sustainable outcomes.

\section{Case Studies}

We illustrate the above theory review with data from two case studies. We looked for case studies where authorities pursued green infrastructureoriented strategies to enhance the resilience of urban or peri-urban ecosystems to disturbance, thereby insuring urban residents against reductions in the ecosystem's capacity to provide services (Table 1).

\section{Vancouver Watersheds}

Over 2 million Metro Vancouver residents depend on three watersheds for their drinking water: Capilano (19535 ha), Seymour (12375 ha) and Coquitlam (18370 ha). Precipitation in these mountainous watersheds ranges from 2000 to 5000 $\mathrm{mm}$ annually; extreme precipitation has the potential to cause landslides and soil erosion, resulting in turbidity. The presence of fine particulates makes it more difficult to ensure treatment eliminates pathogens, such as Giardia and Cryptosporidium (Betancourt and Rose 2004).

Logging in the lower reaches of the Capilano reservoir between 1918 and 1931 raised concerns that the region's drinking water quality was at risk. In 1926, the Greater Vancouver Water District was formed, and in 1927, the Province of British Columbia (BC) gave the city a 999-year lease on the three watersheds; the lease specified that the primary management objective was to maintain water quality, and commercial logging was not allowed (Koops 1997). The Water District's first Chief
Commissioner, Ernest Cleveland, showed remarkable foresight, arguing in December of 1936 against resource extraction or human activities within the watersheds:

I would not attempt to set a value on the watershed lands... as they constitute an almost invaluable asset of the District permitting the complete and entire control of the purity of the water supply for all time... (Koops 1997)

As decades of logging across BC led to scarcity of old-growth timber, and as the $\mathrm{BC}$ government shifted towards sympathetic administration of the forest sector (Green 2007; Marchak 2011), industry leaders and the Forest Service pursued a variety of strategies to $\log$ community watershed reserves throughout the province despite legal constraints. They argued that logging would allow "over-mature, decadent and diseased" old growth to be replaced with thrifty stands of growing timber, thereby reducing the likelihood of insect infestations, disease and forest fires, which were described as leading to water-quality issues (C.D. Schultz $\delta$ Company Ltd. 1959). Thus, timber production and drinking water provision were repackaged as compatible.

Old-growth forest scarcity, prevailing notions of scientific forestry and the logging industry's capture of government institutions at both the provincial and regional levels, resulted in provincial and civic authorities signing in 1967 an amendment to the lease, thereby requiring that the Water District submits 5-year logging plans to the province's Chief Forester. By 1994, $300 \mathrm{~km}$ of logging roads had been built and 5000 hectares of old-growth forest had been logged. Meanwhile, as industrial resource extraction expanded in watersheds across BC, boil water advisories became more frequent (Koops 1997).

By the late 1980s, emerging ecosystem-based management approaches highlighted the importance of old-growth forests and their biodiversity, undermining the scientific credentials of forestry practices prevailing in BC (Franklin 1992; Clayoquot Sound Scientific Panel 1995; Green 2000). For instance, research showed that stand-replacing wildfires that clearcut logging supposedly mimicked occurred very infrequently in BC's coastal rainforests. Furthermore, clearcut logging simplified stand structure, reducing habitat for oldgrowth-dependent species (MacKinnon and Saunders 2012). Although disease and insect infestations had been observed at times in confined areas 


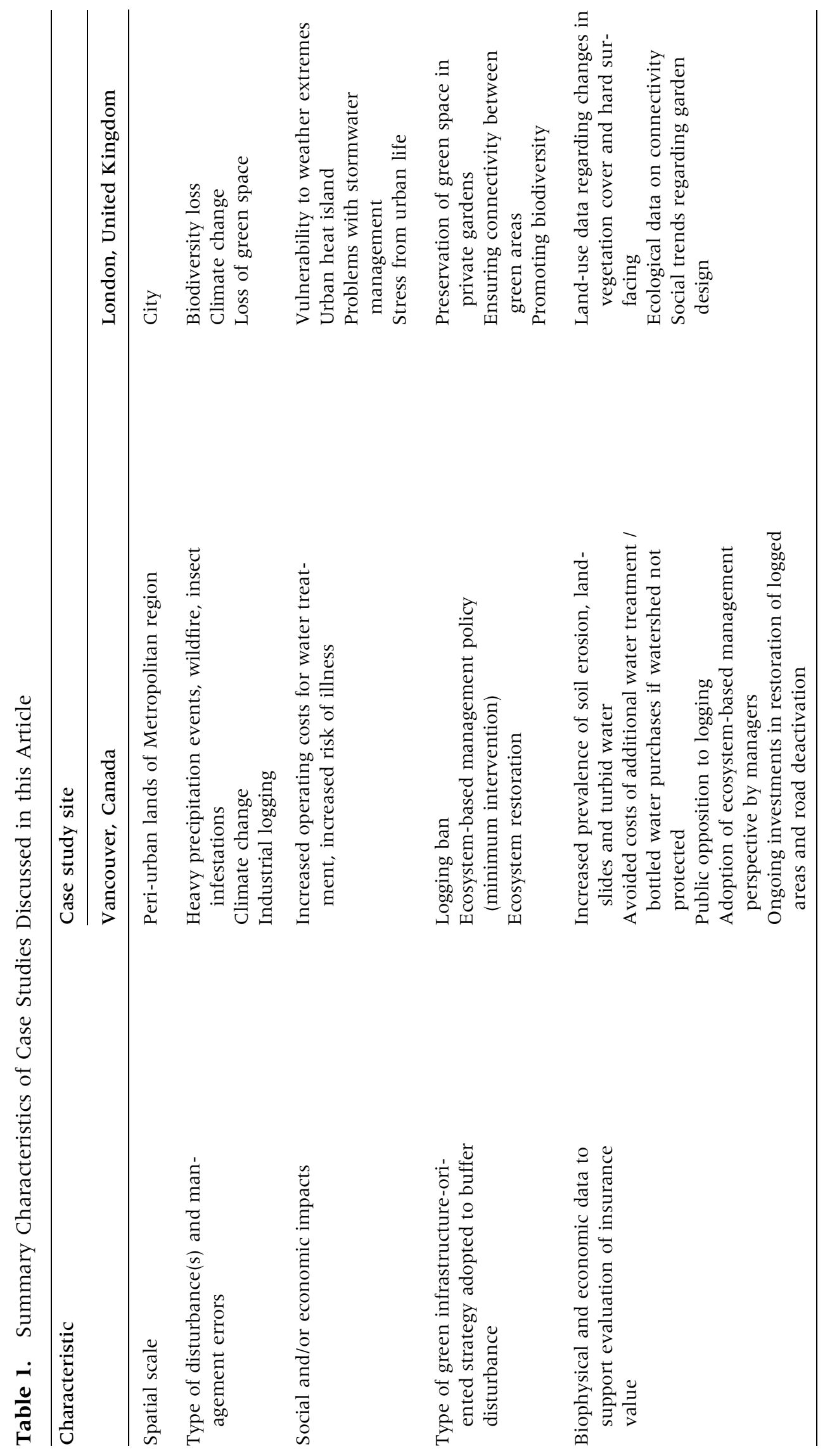


within the watersheds, not all tree species were vulnerable; only some of the trees in an area would be killed, and no credible scientific evidence had been produced establishing that the relatively diverse old-growth stands in the watershed were at risk of being denuded by insects or disease. Ironically, logging was increasing the risk of infestation by insects that thrive on logging slash and root injuries (Feller 1991). Far from reducing the risk of forest fire, fires were sometimes caused by logging operations and even-aged plantations were at greater risk of "crown fire" wherein fire spreads rapidly from crown to crown than the old-growth stands they replaced (Feller 1991; Hume 1991). Facing increased incidents of landslides, turbid water- and gastroenteritis-related illnesses, Vancouver residents began opposing logging in their watersheds. Feeling public pressure (Etkin 1996), civic officials curtailed extraction levels. Industrial logging ended in 1995. In 2002, the Greater Vancouver Watershed District gave notice to the province that it was cancelling the Amending Indenture that permitted logging, effective June 2004 (Carline 2002).

Metro Vancouver's current watershed management policy takes an ecosystem-based management approach, securing biodiversity and ecosystem services through minimum intervention and working with the forest's natural disturbance regime, permitting "natural processes, such as forest succession, interactions of plants and animals, wildfires, and erosion" to unfold (Greater Vancouver Regional District 2002). Access remains severely restricted. To reduce the risk of landslides, logging roads are being deactivated and cutblocks revegetated. However, the lag time before forest canopy is re-established implies that soil erosion and the risk of landslide will be above background level for some years still. Furthermore, following a tragedy involving contaminated drinking water in Walkerton, Ontario in May 2000, it was no longer permissible to rely on treatment via chlorination without filtration. In 2009, Metro Vancouver opened the CAD \$820-million Seymour-Capilano Filtration Plant, which filters out sediments, microorganisms and then treats the drinking water with ozone, UV and finally chlorine. Since erosion and landslides are less frequent in old growth, reduced turbidity means lower operating costs and allows less chlorine to be used to treat the water than would have been the case if logging had continued. Vancouver residents' restored confidence in their drinking water is illustrated by dwindling sales of bottled water (City of Vancouver 2012).

The Vancouver watershed case provides an instructive instance of civic officials initially attending to ignoring and then rediscovering insurance value (though to our knowledge, such terminology was not used and they did not develop monetary estimates of insurance value). In drawing insights from this case study, it is necessary to differentiate between two types of benefits secured by the decision to protect the watersheds. First, the cessation of logging secured native biodiversity over the long term (Franklin 1992; Greater Vancouver Regional District 2002; Pojar 2010; MacKinnon and Saunders 2012). Second, the decision enhanced insurance value provided by the watersheds by reducing the likelihood that a disturbance would trigger a regime shift involving an enduring reduction of ecosystem services, including water quality and supply. Protecting public health in the event of such a shift would have increased the costs of water treatment and required higher levels of chlorine, likely resulting in many residents deciding to drink bottled water.

Looking forward, in those portions of BC's coastal temperate rainforests that are off limits to industrial logging-such as Vancouver's watersheds-unmitigated climate change is deemed to represent the greatest risk for a regime shift that would cause severe loss in ecosystem services. Pojar (2010) reviewed observed and anticipated ecosystem changes from climate change in $\mathrm{BC}$ and concluded that "landscapes with intact, functional natural ecosystems probably will be better equipped to accommodate, adapt to and recover from the impacts of climate change than industrialised landscapes". This lends further support to Metro Vancouver's decision to manage the old-growth forests in the watersheds using minimum intervention.

\section{London Gardens}

The concept of green infrastructure emphasizes connectivity, highlighting the importance of green spaces that link larger parks and open spaces in the city with green suburbs (Cameron and others 2012). Less-emphasized green spaces, such as private gardens, are often under strong development pressure (Kronenberg 2015b). In this case study, we present activities undertaken in London regarding private gardens, which occupy 37900 ha or $24 \%$ of the greater city area, to illustrate the relevance of the insurance value of urban green infrastructure.

At least since 2000, London authorities have recognized the importance of green urban areas to mitigate the urban heat island effect, support adaptation to climate change and provide other 
ecosystem services to urban inhabitants. They also realized that the green infrastructure in this city was declining and hence also the services it provides. One example of this trend was the conversion of private gardens, which were literally "changing from green to grey" as a result of pavement and construction. These threats resulted from the behaviour of individual homeowners, with cultural changes affecting garden design-for instance, treating a garden as yet another room, adjacent to a house, rather than as a living green space. Similar trends have been observed in other British cities (see Warhurst and others 2014). A report commissioned by the London Wildlife Trust (Smith and others 2011) indicates that the vegetated cover of London's gardens declined from 25000 ha in $1998-1999$ to 22000 ha in 2006-2008, whereas hard surfacing in gardens increased from 9900 ha to 13000 ha. Meanwhile, the area covered with garden buildings (such as sheds and greenhouses) increased by 1000 ha. Simultaneously, the authorities recognized that as a result of citizen preferences regarding vegetation (as well as of the above loss of garden greenery), garden spaces were becoming less biodiverse. Because gardens are privately owned and managed, the authorities saw an increasing need to involve citizens in biodiversity conservation and stewardship.

Accordingly, London authorities put increasing effort into protecting urban nature, with a focus on biodiversity. In 2000, the multi-stakeholder London Biodiversity Partnership published the first volume of the London Biodiversity Action Plan (London Biodiversity Partnership 2000), which was followed by a series of specific Action Plans published by the London boroughs and the City of London. The plans focused on different habitats (including private gardens) and species. In 2002, the Mayor of London adopted a biodiversity strategy for the city (Mayor of London 2002), which highlighted the many benefits of biodiversity conservation. The strategy brought together different initiatives to protect habitats in London, and underlined the need to promote biodiversity conservation in all of those initiatives. Biodiversity conservation was meant to generate social, ecological and economic value, which required the preservation of different types of habitats, including private gardens considered "of immense value as wildlife habitat" and for human health. City authorities recognized that the combined effect of reduced vegetated area and reduced biodiversity were affecting ecosystem connectivity and climate change adaptation capacity, and that these threats were amplified by climate change, which increased the prevalence of weather extremes. They also understood that biodiversity in green infrastructure was key to maintain ecosystem services, making the urban ecosystem more resilient to disturbances (London Assembly Environment Committee 2005; Mayor of London 2011; Smith and others 2011).

In response to this trend, the London Wildlife Trust, in cooperation with city authorities, launched the "Garden for a Living London" campaign in 2008, focusing on private gardens (Smith and others 2011). This campaign's aim was to transform the city's 3.3 million gardens into a "network of mini nature reserves", providing habitat for wildlife and ultimately making London more resilient to climate change. The London Wildlife Trust provided city residents with information on making gardens biodiversity friendly as part of an overall strategy to ensure connectivity and redundancy of green infrastructure components. These awareness-raising activities were meant to use gardens as corridors to link other green spaces and to help reverse trends in garden design that cause the loss of biodiversity and greenery (Smith and others 2011). Furthermore, such actions are meant to enhance microclimate regulation (including moderating the effects of heat waves), managing riverine and stormwater flooding and surface water, and adapting habitats (helping species to adapt) in the face of climate change.

What does the insurance value metaphor instruct us about the London case of private urban gardens? First, city authorities recognized the value of private gardens in adapting to climate change and in connecting other parts of urban green infrastructure. Second, they recognized that it was not enough that the gardens be green. To better respond to threats or to possible management error (for example, accidental introduction of a disease), both the biodiversity of these private spaces and their connectivity matter. If only one tree species was to be grown in private gardens in London, the gardens might provide the desired cooling effect. However, such a monoculture could prove vulnerable to a pest outbreak and if many of the trees succumbed, the city would experience an enduring loss in a critical ecosystem services with direct economic consequences for urban residents, such as increased health costs and expenditures on air conditioning. To provide insurance value, garden ecosystems must be resilient. Although city authorities and partner organizations did not, to our knowledge, use the terminology or develop monetary estimates of insurance value, their decisions were as if informed by this metaphor since they recognized the relevance of resilience and 
they invested in the biodiversity of green infrastructure.

Moving forward, the insurance value metaphor can help the authorities harness the collaboration of landowners and to support arguments in favour of the expenditure of public funds in supporting urban gardeners to rebuild biodiversity and to restore gardens that have been paved. The city can point out that like an insurance policy taken out by the city, the collective effect of many biodiverse gardens is to position the city better for climate change and other threats. Indeed, this case study indicates an attempt to address ecosystem management errors committed by individual landowners, since the cumulative effects of their management decisions were undermining resilience of the whole urban ecosystem.

\section{Discussion}

Urban residents stand to benefit from urban ecosystems that are resilient so as to reduce the risk of an enduring loss of ecosystem services due to disturbance or management error. The insurance value metaphor can be applied to inform urban planning and decision making oriented to invest in ecosystem resilience. It prompts analysis of the components of urban ecosystems that support resilience and helps to target investments in green infrastructure and the restoration of urban ecosystems.

The two case studies illustrate the role of ecosystem resilience in insuring urban areas against disturbance. Improving resilience required urban authorities to identify relevant ecosystem components and critical properties necessary to prevent abrupt changes in the face of disturbance. For Vancouver, these were old-growth forests high in biodiversity; and in London, private gardens ensuring connectivity between other green spaces.

We suggest that three aspects deserve particular attention when incorporating the concept of insurance value into urban decision making and planning. First, investments in ecosystem restoration to increase insurance capacity and reduce risk or vulnerability should not require inputs or actions that degrade non-urban ecosystems. While a small number of individual cities can secure local sustainability by eroding global sustainability, such a strategy cannot be generalized since urban regions ultimately depend on a viable biosphere (Elmqvist and others 2013).

Second, our literature review and case studies suggest uncertainty and ignorance are overarching challenges for managing urban ecosystems for their insurance value. We do not know what may happen and what kind of insurance we may need (Faber and others 1992; Dale and others 1998). The key question is how to ensure enough diversity in the green infrastructure system to account for multiple and often unexpected disturbances. Few decision makers or decision-making processes are sufficiently forward looking at present to purposefully attend to insurance value. Another challenge is identifying the relevant level of investment that would ensure that the green infrastructure's resilience is above the threshold wherein recovery from disturbance is likely (Baumgärtner and Strunz 2014).

Third, insurance value was not monetized to support decisions in either of the case studies and doing so would not necessarily have been helpful. Although insurance value can be a powerful metaphor to guide green infrastructure strategies, there are drawbacks to interpreting the concept narrowly in the logic of monetary costs and benefits. Some authors note that investments in green infrastructure to enhance insurance value are likely to bring more economic benefits than costs, at least in the long term (Costanza and others 2006). In the short term, however, high market values of real estate in urban areas will frequently outcompete the economic value that can be attributed to insurance value, tilting the math against resilience investments on sites where development is permissible. Furthermore, those harnessing the metaphor of insurance value risk inadvertently advancing the notion that we could substitute ecological resilience with financial insurance, i.e. that investments in resilience and purchasing financial insurance are largely equivalent, and ecosystem users can select the cheapest option. Despite its direct relation with economic value, insurance value may be seen as being weakly comparable or even incommensurable in monetary terms (Kronenberg 2015a), and hence we advise against its financialization.

\section{Conclusions and Policy RECOMMENDATIONS}

To date, insurance value offered by urban ecosystems has largely been neglected in urban decisionmaking processes, where decisions with a focus on short-term benefits are often taken at the expense of increased risk of higher costs in the long term. We have discussed the potential contribution that the insurance value metaphor can make to urban planning and investment decisions. The two case 
studies examined here, where civic authorities eventually identified and addressed the conditions and attributes necessary to secure resilience through investments in green infrastructure in and around cities, can be seen as successful cases of insurance value-oriented strategies, even if the concept may have not been explicitly used and monetary estimates of insurance value were not produced. The case studies are instructive in that they suggest that if insurance value is factored in the decision-making matrix-as ecological economics theory suggests it should-levels of ecosystem resilience that secure long-term conditions to sustain human health and well-being are more likely to be achieved. Recognition of insurance value justifies higher investments in green infrastructure, more precautionary approaches to urban ecosystem management, and enhanced efforts to tackle drivers of environmental change.

Although we call for a broader recognition of the long-term social and economic importance of insurance value, we also advise against its monetization in support of decision making, not only because data and analytical demands are high, but primarily because insurance value affects nonmarginal changes that remove traditional welfare analysis from the domain where it is theoretically consistent (Gowdy 2005) and because monetization risks advancing the notion that losses in insurance value from ecosystem degradation can be compensated for through financial capital. Instead, we make a case for an ecological economic analysis and management oriented to avert regime shifts so as to secure the sustained delivery of ecosystem services underpinning long-term conditions for well-being.

From the insights gained in our literature review and the case studies examined here, we outline management strategies for green infrastructure that are likely to enhance the insurance value of urban ecosystems: (i) identify potential regime shifts, disturbances and management errors that may impact long-term capacity to sustain ecosystem services from urban and peri-urban ecosystems; (ii) ensure green infrastructure is properly assessed and considered when investment decisions are made (given past tendency to favour grey infrastructure); (iii) ensure sufficient area is devoted to green infrastructure to provide desired ecosystem services; (iv) consider the risks to green infrastructure itself (for example, urban forest that delivers desired ecosystem services may succumb to an infestation or adverse climatic conditions because it is low in diversity) and invest in its resilience (for example, enhance biodiversity); (v) promote a judicious balance of connectivity but also modularity in the urban matrix (for example, restore riparian areas and corridors, but also see value in isolated patches); (vi) restore degraded lands and protect existing green infrastructure; when space is scarce, exploit complementarity of grey and green infrastructure (for example, green roofs); (vii) pay attention to the ecosystem services provided by peri-urban lands, including peri-urban forests and agricultural belts; and (viii) implement innovative policy instruments to protect peri-urban ecosystems, including mechanisms of societal recognition or economic rewards for ecosystem stewards.

We hope that further research will enable refined guidance for investment in insurance value. The above insights can be distilled down to the principle that when making decisions on green infrastructure we should not merely recognize the ecosystem services urban ecosystems provide but also the consequences of plausible regime shifts; making the necessary investments to secure the long-term capacity of ecosystems to provide ecosystem services in the face of disturbance, change and management error. Due to multiple risks, cities should incorporate principles of response redundancy, functional diversity and landscape multifunctionality in designing green infrastructure.

Finally, civic authorities and residents should recognize that there is a limit to the resilience of urban ecosystems. When it comes to insurance purchased on markets, certain actions or failure to take action can nullify the policy. Likewise for ecosystems, the insurance metaphor indicates that beyond certain disturbance thresholds, urban green infrastructure will lose its buffering capacity. If climate change and other global-scale drivers of environmental change are not mitigated, regime changes can be anticipated in many of the ecosystems that deliver ecosystem services to cities. Cities have experimented with a range of policy options for mitigating climate change (Castán Broto and Bulkeley 2013) even when effective national or international action was lacking; such efforts should be redoubled.

\section{ACKNOWLEDGEMENTS}

We appreciate the helpful comments of two anonymous reviewers. The BC Tap Water Alliance's extensive archives provided invaluable information on the Vancouver watersheds. Thora Gislason of Metro Vancouver kindly helped track down historical documents. Charlotte McLoed assisted with editing. We also acknowledge the BioDiversa URBES project, the GREEN SURGE EU FP7 collab- 
orative project (FP7-ENV.2013.6.2-5-603567) and the OpenNESS EU FP7 ENVIRONMENT project (code 308428).

\section{OPEN ACCESS}

This article is distributed under the terms of the Creative Commons Attribution 4.0 International License (http://creativecommons.org/licenses/by/ 4.0/), which permits unrestricted use, distribution, and reproduction in any medium, provided you give appropriate credit to the original author(s) and the source, provide a link to the Creative Commons license, and indicate if changes were made.

\section{REFERENCES}

Abson D, Fraser E, Benton T. 2013. Landscape diversity and the resilience of agricultural returns: a portfolio analysis of landuse patterns and economic returns from lowland agriculture. Agric Food Secur 2:1-15.

Admiraal JF, Wossink A, de Groot WT, de Snoo GR. 2013. More than total economic value: how to combine economic valuation of biodiversity with ecological resilience. Ecol Econ 89:115-22.

Baumgärtner S. 2007. The insurance value of biodiversity in the provision of ecosystem services. Nat Resour Model 20:87-127.

Baumgärtner S, Strunz S. 2014. The economic insurance value of ecosystem resilience. Ecol Econ 101:21-32.

Bengtsson J, Angelstam P, Elmqvist T, Emanuelsson U, Folke C, Ihse M, Moberg F, Nyström M. 2003. Reserves, resilience and dynamic landscapes. AMBIO 32:389-96.

Betancourt WQ, Rose JB. 2004. Drinking water treatment processes for removal of Cryptosporidium and Giardia. Vet Parasitol $126: 219-34$

Cameron RWF, Blanuša T, Taylor JE, Salisbury A, Halstead AJ, Henricot B, Thompson K. 2012. The domestic garden-its contribution to urban green infrastructure. Urban Forestry $\delta$ Urban Greening 11:129-37.

Carline J. 2002. Cancelation of amending indenture dated March 7, 1967. Letter to Jon O'Riordan, Province of British Columbia, June 21. Greater Vancouver Watershed District, Vancouver.

Castán Broto V, Bulkeley H. 2013. A survey of urban climate change experiments in 100 cities. Glob Environ Change 23:92-102.

C.D. Schultz \& Company Ltd. 1959. The Practice of Watershed Management on the Watershed of the Greater Vancouver Water District. Vancouver.

City of Vancouver. 2012. Greenest City 2020 Action Plan. Vancouver.

Clayoquot Sound Scientific Panel. 1995. sustainable ecosystem management in Clayoquot sound: planning and practices. Victoria: Clayoquot Sound Scientific Panel.

Costanza R, Mitsch WJ, Day JW. 2006. A new vision for New Orleans and the Mississippi delta: applying ecological economics and ecological engineering. Front Ecol Environ 4:46572 .

Crépin A-S, Biggs R, Polasky S, Troell M, de Zeeuw A. 2012. Regime shifts and management. Ecol Econ 84:15-22.
Dale VH, Lugo AE, MacMahon JA, Pickett ST. 1998. Ecosystem management in the context of large, infrequent disturbances. Ecosystems 1:546-57.

Depietri Y, Renaud F, Kallis G. 2012. Heat waves and floods in urban areas: a policy-oriented review of ecosystem services. Sustain Sci 7:95-107.

Di Falco S, Chavas J-P. 2008. Rainfall shocks, resilience, and the effects of crop biodiversity on agroecosystem productivity. Land Econ 84:83-96.

Ehrlich P, Ehrlich A. 1981. Extinction: the causes and consequences of the disappearance of species. New York: Random House.

Elmqvist T, Folke C, Nyström M, Peterson G, Bengtsson J, Walker B, Norberg J. 2003. Response diversity, ecosystem change, and resilience. Front Ecol Environ 1:488-94.

Elmqvist T, Fragkias M, Goodness J, Güneralp B, Marcotullio PJ, McDonald RI, Parnell S, Schewenius M, Sendstad M, Seto KC, Wilkinson C, Eds. 2013. Urbanization, biodiversity and ecosystem services: challenges and opportunities. Dordrecht: Springer.

Elton CS. 1958. The ecology of invasions by plants and animals. London: Methuen.

Etkin A. 1996. When common sense fails: public debate over watershed management in British Columbia: a case study. Burnaby, BC: Masters Thesis, Simon Fraser University.

European Commission. 2013. Green Infrastructure (GI): Enhancing Europe's Natural Capital. Brussels: European Commission.

Faber M, Manstetten R, Proops JL. 1992. Humankind and the environment: an anatomy of surprise and ignorance. Environ Values 1:217-41.

Farrugia S, Hudson MD, McCulloch L. 2013. An evaluation of flood control and urban cooling ecosystem services delivered by urban green infrastructure. Int J Biodivers Sci Ecosyst Serv Manag 9:136-45.

Feller M. 1991. Comments on watershed management evaluation and policy review. Greater vancouver watershed management evaluation and policy review. Vancouver: Economic and Engineering Services Inc. p 186-95.

Folke C, Holling CS, Perrings C. 1996. Biological diversity, ecosystems, and the human scale. Ecol Appl 6(4):1018-24.

Franklin JF. 1992. Scientific basis for new perspectives in forests and streams. In: Naiman RJ, Ed. Watershed management: balancing sustainability and environmental change. New York: Springer. p 24-69.

Friess DA, Phelps J, Garmendia E, Gómez-Baggethun E. 2015. Payments for Ecosystem Services (PES) in the face of external biophysical stressors. Glob Environ Change 30:31-42.

Gómez-Baggethun E. 2010. To Ecologise economics or to economise ecology: theoretical controversies and operational challenges in ecosystem services valuation. Doctoral dissertation, Universidad Autónoma de Madrid.

Gómez-Baggethun E. 2013. Valoración económica y complejidad ecológia. Implicaciones para la economía verde. Cuaderno Interdisciplinar de Desarrollo Sostenible 10:27-54.

Gómez-Baggethun E, Barton DN. 2013. Classifying and valuing ecosystem services for urban planning. Ecol Econ 86:235-45.

Gowdy J. 2005. Toward a new welfare economics for sustainability. Ecol Econ 53:211-22.

Greater Vancouver Regional District. 2002. Watershed Management Plan. Vancouver: Greater Vancouver Regional District. 
Green TL. 2000. Confusing liquidation with income in BC's forests: economic analysis and the BC forest industry. Ecol Econ 34:33-46.

Green TL. 2007. Improving human wellbeing and ecosystem health on BC's coast: the challenge posed by historic resource extraction. J Bioecon 9:245-63.

Grime JP. 1997. Biodiversity and ecosystem function: the debate deepens. Science 277:1260-1.

Gross K, Cardinale BJ, Fox JW, Gonzalez A, Loreau M, Polley HW, Reich PB, van Ruijven J. 2014. Species richness and the temporal stability of biomass production: a new analysis of recent biodiversity experiments. Am Nat 183:1-12.

Hanski I. 1999. Metapopulation ecology. Oxford: Oxford University Press.

Holling CS. 1973. Resilience and stability of ecological systems. Annu Rev Ecol Syst 4:1-23.

Horizon 2020 Expert Group. 2015. Towards an EU Research and Innovation Policy Agenda for Nature-Based Solutions \& ReNaturing Cities. Brussels: European Commission. Directorate General for Research and Innovation, Climate Action, Environment, Resource Efficiency and Raw Materials.

Hubacek K, Kronenberg J. 2013. Synthesizing different perspectives on the value of urban ecosystem services. Landsc Urban Plan 109:1-6.

Hume S. 1991. Challenge for watershed logging. Vancouver Sun: May 10, A15

Hutchinson GE. 1959. Homage to Santa Rosalia or why are there so many kinds of animals? Am Nat 93:145-59.

Jansson ̊. 2013. Reaching for a sustainable, resilient urban future using the lens of ecosystem services. Ecol Econ 86:28591.

Jenerette GD, Harlan SL, Stefanov WL, Martin CA. 2011. Ecosystem services and urban heat riskscape moderation: water, green spaces, and social inequality in Phoenix, USA. Ecol Appl 21:2637-51.

Koch EW, Barbier EB, Silliman BR, Reed DJ, Perillo GM, Hacker SD, Granek EF, Primavera JH, Muthiga N, Polasky S. 2009. Non-linearity in ecosystem services: temporal and spatial variability in coastal protection. Front Ecol Environ 7:29-37.

Koellner T, Schmitz OJ. 2006. Biodiversity, ecosystem function, and investment risk. BioScience 56:977-85.

Koops W. 1997. Seymourgate. The off-catchment lands of the lower Seymour valley: an investigation. Vancouver: BC Tap Water Alliance.

Kronenberg J. 2014. What can the current debate on ecosystem services learn from the past? Lessons from economic ornithology. Geoforum 55:164-77.

Kronenberg J. 2015a. Betting against human ingenuity: the perils of the economic valuation of nature's services. BioScience 65:1096-9.

Kronenberg J. 2015b. Why not to green a city? Institutional barriers to preserving urban ecosystem services. Ecosyst Serv $12: 218-27$.

Levin SA. 1998. Ecosystems and the biosphere as complex adaptive systems. Ecosystems 1:431-6.

Limburg KE, O'Neill RV, Costanza R, Farber S. 2002. Complex systems and valuation. Ecol Econ 41:409-20.

Liu J, Hull V, Batistella M, DeFries R, Dietz T, Fu F, Hertel TW, Izaurralde RC, Lambin EF, Li S, Martinelli LA, McConnell WJ, Moran EF, Naylor R, Ouyang Z, Polenske KR, Reenberg A, de Miranda Rocha G, Simmons CS, Verburg PH, Vitousek PM,
Zhang F, Zhu C. 2013. Framing sustainability in a telecoupled world. Ecol Soc 18(2):26. doi:10.5751/ES-05873-180226.

London Assembly Environment Committee. 2005. Crazy paving: the environmental importance of London's front gardens. London: Greater London Authority.

London Biodiversity Partnership. 2000. London Biodiversity Action Plan. London: London Biodiversity Partnership.

Loreau M. 2010. From populations to ecosystems: theoretical foundations for a new ecological synthesis. Princeton: Princeton University Press.

Loreau M, Naeem S, Inchausti P, Bengtsson J, Grime JP, Hector A, Hooper DU, Huston MA, Raffaelli D, Schmid B, Tilman D, Wardle DA. 2001. Biodiversity and ecosystem functioning: current knowledge and future challenges. Science 294:804-8.

Lundberg J, Moberg F. 2003. Mobile link organisms and ecosystem functioning: implications for ecosystem resilience and management. Ecosystems 6:87-98.

MacArthur R. 1955. Fluctuations of animal populations and a measure of community stability. Ecology 36:533-6.

MacKinnon A, Saunders SC. 2012. Incorporating concepts of historical range of variation in ecosystem-based management of British Columbia's coastal temperate rainforest. In: Wiens JA, Hayward GD, Safford HD, Giffen CM, Eds. Historical environmental variation in conservation and natural resource management. Oxford: Wiley. p 166-75.

Mäler K-G. 2006. Environment and decision-making under risk and uncertainty. In: Aronsson T, Axelsson R, Brännlund R, Eds. The theory and practice of environmental and resource economics: essays in Honour of Karl-Gustaf Lèofgren. Cheltenham: Edward Elgar. p 21-44.

Mäler K-G. 2008. Sustainable development and resilience in ecosystems. Environ Resource Econ 39:17-24.

Marchak P. 2011. Green gold: the forest industry in British Columbia. Vancouver: UBC Press.

Mayer AL, Rietkerk M. 2004. The dynamic regime concept for ecosystem management and restoration. BioScience 54:101320.

Mayor of London. 2002. Connecting with London's nature: the Mayor's biodiversity strategy. London: Greater London Authority.

Mayor of London. 2011. Managing risks and increasing resilience: the Mayor's climate change adaptation strategy. London: Greater London Authority.

McCann KS. 2000. The diversity-stability debate. Nature 405:228-33.

Mori AS, Furukawa T, Sasaki T. 2013. Response diversity determines the resilience of ecosystems to environmental change. Biol Rev 88:349-64.

Nyström M, Folke C. 2001. Spatial resilience of coral reefs. Ecosystems 4:406-17.

Pascual U, Muradian R, Brander L, Gómez-Baggethun E, Martin-López B, Verma M, Armsworth P, Christie M, Cornelissen H, Eppink F, Farley J, Loomis LP. 2010. The economics of valuing ecosystem services and biodiversity. In: Kumar P, Ed. The economics of ecosystems and biodiversity: ecological and economic foundations. London: UNEP/Earthscan. p 183-256.

Perrings C. 1995. Biodiversity conservation as insurance. In: Swanson TM, Ed. The economics and ecology of biodiversity decline: the forces driving global change. Cambridge: Cambridge University Press. p 69-78. 
Pojar J. 2010. A new climate for conservation: nature, carbon and climate change in British Columbia. Vancouver: Working Group on Biodiversity, Forests and Climate.

Quaas MF, Baumgärtner S. 2008. Natural vs. financial insurance in the management of public-good ecosystems. Ecol Econ 65:397-406.

Schläpfer F, Tucker M, Seidl I. 2002. Returns from hay cultivation in fertilized low diversity and non-fertilized high diversity grassland. Environ Resour Econ 21:89-100.

Seto KC, Reenberg A, Boone CG, Fragkias M, Haase D, Langanke T, Marcotullio P, Munroe DK, Olah B, Simon D. 2012. Urban land teleconnections and sustainability. Proc Natl Acad Sci 109:7687-92.

Smith C, Dawson D, Archer J, Davies M, Frith M, Hughes E, Massini P. 2011. From green to grey; observed changes in garden vegetation structure in London, 1998-2008. London: London Wildlife Trust.

Strunz S, Baumgärtner S. 2010. Management of ecosystem resilience as optimal self-protection: a simple, but often non-convex problem. Unpublished working paper.

Sukhdev P, Wittmer H, Schröter-Schlaack C, Nesshöver C, Bishop J, ten Brink P, Gundimeda H, Kumar P, Simmons B.
2010. The economics of ecosystems and biodiversity: mainstreaming the economics of nature: a synthesis of the approach, conclusions and recommendations of TEEB. TEEB.

Tzoulas K, Korpela K, Venn S, Yli-Pelkonen V, Kaźmierczak A, Niemela J, James P. 2007. Promoting ecosystem and human health in urban areas using green infrastructure: a literature review. Landsc Urban Plan 81:167-78.

Walker BH. 1992. Biodiversity and ecological redundancy. Conserv Biol 6:18-23.

Wamsler C, Brink E, Rivera C. 2013. Planning for climate change in urban areas: from theory to practice. J Clean Prod 50:6881.

Warhurst JR, Parks KE, McCulloch L, Hudson MD. 2014. Front gardens to car parks: changes in garden permeability and effects on flood regulation. Sci Total Environ 485-486:329-39.

White PS, Pickett ST. 1985. Natural disturbance and patch dynamics: an introduction. In: Pickett ST, White PS, Eds. The ecology of natural disturbance and patch dynamics. Orlando: Academic Press. p 3-13.

Yachi S, Loreau M. 1999. Biodiversity and ecosystem productivity in a fluctuating environment: the insurance hypothesis. Proc Natl Acad Sci 96:1463-8. 